\title{
PENCEGAHAN PENYAKIT ISPA MELALUI PEMANFAATAN BARANG BEKAS DAN SAMPAH DI DESA WOTANNGARE KECAMATAN KALITIDU BOJONEGORO
}

\author{
(PREVENTION OF ARI DISEASE THROUGH UTILIZATION OF USED GOODS \\ AND RUBBISH IN THE WOTANNGARE VILLAGE, KALITIDU, BOJONEGORO)
}

\author{
Lala Pitaloka \\ Program Studi Kesehatan Masyarakat, Fakultas Kesehatan Masyarakat, \\ Universitas Airlangga \\ e-mail: lala.pitaloka-2016@fkm.unair.ac.id
}

\begin{abstract}
Acute Respiratory Infection (ARI) is a major public health problem and a major disease causing illness and death in infants and toddlers. Some ARI diseases, one of which is pneumonia. Pneumonia is a respiratory infection that is the main killer of children under five in Indonesia, so that health problems need to be addressed. One of the factors causing ARI, is closely related to environmental conditions. Smoking habits in the house and burning trash have the potential to cause ARI. Efforts to prevent ARI are carried out through health intervention activities as a form of providing knowledge and understanding as well as changes in mindset and behavior for the community. This intervention is carried out through the use of used goods and rubbish so that it can be managed properly and reused. The focus of this intervention activity is as an effort to prevent ARI through the use of used goods and garbage in the surrounding environment. In addition, an understanding of good waste management and the use of used goods is also given so that they can be reused. It is hoped that this intervention will have a positive impact and enthusiasm on the community so that it can be useful for daily life and improve public health and environmental health.
\end{abstract}

Keywords: ARI disease, toddler, smoking, burning garbage, utilization of used goods

\begin{abstract}
abstrak
Penyakit Infeksi Saluran Pernafasan Akut (ISPA) merupakan masalah kesehatan masyarakat yang utama dan penyakit utama penyebab kesakitan dan kematian bayi dan balita. Beberapa penyakit ISPA, salah satunya adalah pneumonia. Pneumonia merupakan penyakit ISPA yang menjadi pembunuh utama balita di Indonesia, sehingga masalah kesehatan tersebut perlu untuk diperhatikan. Salah satu faktor penyebab penyakit ISPA, berkaitan erat dengan kondisi lingkungan. Kebiasaan merokok di dalam rumah dan membakar sampah berpotensi menyebabkan terjadinya penyakit ISPA. Upaya pencegahan penyakit ISPA dilakukan melalui kegiatan intervensi kesehatan sebagai wujud memberikan pengetahuan dan pemahaman serta perubahan pola pikir dan perilaku kepada masyarakat. Kegiatan intervensi ini dilakukan melalui pemanfaatan barang bekas dan sampah agar dapat dikelola dengan baik dan dimanfaatkan kembali. Fokus kegiatan intervensi ini sebagai upaya pencegahan penyakit ISPA melalui pemanfaatan barang bekas dan sampah di lingkungan sekitar. Selain itu, diberikan juga pemahaman mengenai pengelolaan sampah yang baik dan pemanfaatan barang bekas agar dapat digunakan kembali. Diharapkan, kegiatan intervensi ini memberikan dampak positif dan antusiasme kepada masyarakat agar dapat bermanfaat untuk kehidupan sehari-hari dan meningkatkan kesehatan masyarakat dan kesehatan lingkungan.
\end{abstract}

Kata kunci: penyakit ISPA, balita, merokok, pembakaran sampah, pemanfaatan barang bekas

10.20473/jlm.v4i2.2020.301-311

Open acces under CC BY-SA license

Creative Commons Attribution-ShareAlike 4.0 International License 


\section{PENDAHULUAN}

Desa Wotanngare merupakan salah satu bagian dari wilayah Kecamatan Kalitidu, Kabupaten Bojonegoro Jawa Timur. Desa Wotanngare memiliki luas wilayah dengan total sebesar 375,68 Ha dan merupakan dataran rendah yang dialiri oleh sungai. Lokasi Desa Wotanngare terletak di kawasan perkantoran, kawasan industri, kawasan wisata dan perbatasan antar kecamatan lain. Total jumlah penduduk Desa Wotanngare sekitar 3275 orang dengan jumlah kepala keluarga yang ada di desa tersebut sebesar 938 kepala keluarga. Dari segi ekonomi, mayoritas penduduk Desa Wotanngare bermata pencaharian pokok sebagai pengusaha kecil, menengah dan besar serta karyawan perusahaan swasta dan pensiunan. Dari segi lingkungan, Desa Wotanngare memiliki potensi air dan sumber daya air yaitu sungai. Selain itu, akses ke lembaga pendidikan dan pelayanan kesehatan memadai dan mudah untuk diakses. Potensi sarana dan prasarana di Desa Wotanngare yaitu mulai dari sarana transportasi, sarana komunikasi dan informasi, sarana air bersih dan sanitasi, sarana peribadatan, sarana kesehatan dan sarana kebersihan juga telah memadai.

Dilihat dari segi kesehatan masyarakat Desa Wotanngare, masih memiliki kasus dan masalah dalam kesehatan diantaranya adalah penyakit ISPA balita dan Gizi kurang balita. Dari dua penyakit tersebut, kasus terbanyak adalah penyakit ISPA balita. Berdasarkan penyebab masalahnya, penyakit ISPA pada balita dipengaruhi oleh beberapa faktor. Kebiasaan masyarakat Desa Wotanngare juga dapat menjadi penyebab dari terjadinya penyakit ISPA. Dikarenakan dari segi pola pikir dan perilaku masyarakat Desa Wotanngare yang masih kurang mengerti dan sadar akan terkait penyakit ISPA. Masyarakat Desa Wotanngare memiliki kebiasaan memusnahkan sampah, organik maupun non organik, yaitu dengan cara dibakar. Sehingga dapat menimbulkan polusi udara yang berasal dari asap pembakaran sampah. Hal ini berpotensi dapat menyebabkan penyakit ISPA dari asap pembakaran tersebut. Selain itu, masih banyak masyarakat Desa Wotanngare, dimana anggota keluarga yang merokok di dalam rumah.

Infeksi Saluran Pernapasan Akut (ISPA) merupakan infeksi saluran pernapasan yang berlangsung sampai 14 hari dan penyakit infeksi akut yang menyerang salah satu bagian dan atau lebih dari saluran nafas mulai dari hidung hingga alveoli (Depkes RI, 2012). Menurut WHO (2012), Infeksi Saluran Pernafasan Akut (ISPA) merupakan penyakit saluran pernafasan akut yang disebabkan oleh agen infeksius yang ditularkan dari manusia ke manusia serta timbulnya gejala sangat cepat yaitu dalam waktu beberapa jam sampai hari. ISPA sendiri meliputi saluran pernafasan bagian atas dan bagian bawah. Apabila ISPA mengenai jaringan paru-paru atau disebut juga ISPA berat maka dapat menjadi pneumonia.

Berdasarkan data laporan rutin Subdit ISPA Tahun 2018, didapatkan insiden yaitu per 1000 balita di Indonesia sebesar 20,06\%. Pada tahun 2018, angka kematian akibat pneumonia pada balita sebesar 0,08\%. Angka kematian akibat pneumonia pada kelompok bayi lebih tinggi yaitu sebesar $0,16 \%$ dibandingkan pada kelompok anak umur 1-4 tahun sebesar 0,05\% (Profil Kesehatan Indonesia, 2018). Menurut WHO, Penyakit ISPA merupakan salah satu penyebab kematian yang sering terjadi pada anak di negara berkembang. ISPA menyebabkan 4 dari 15 juta perkiraan kematian pada balita yaitu berusia dibawah 5 tahun dan sebanyak dua per tiga dari kematian tersebut terjadi pada bayi. Penyakit ISPA menjadi salah satu masalah kesehatan masyarakat yang perlu diperhatikan (Wahyuningsih et al, 2017). 
Penyakit ISPA merupakan penyakit utama yang menjadi penyebab kesakitan dan kematian bayi dan balita. Berdasarkan keadaan tersebut, ada kaitan erat dengan berbagai kondisi yang melatarbelakangi terjadinya penyakit ISPA, salah satunya yaitu kondisi lingkungan baik polusi di dalam rumah dan di luar rumah berupa asap maupun debu (Depkes RI, 2012).

Salah satu penyebab penyakit ISPA yang terjadi di Desa Wotanngare, dikarenakan kebiasaan dan perilaku serta pola pikir masyarakat di wilayah Desa Wotanngare terhadap kesehatan dan lingkungan. Kebiasan memusnahkan sampah sehari-hari dengan cara dibakar dapat menimbulkan polusi berupa asap pembakaran di lingkungan. Sehingga apabila asap pembakaran tersebut terhirup setiap hari oleh masyarakat mulai dari bayi, balita hingga dewasa dapat mempengaruhi kesehatannya. Salah satunya asap pembakaran sampah dapat menyebabkan penyakit ISPA pada balita. Selain itu, anggota keluarga yang memiliki kebiasaan merokok di dalam rumah juga berpotensi menyebabkan terjadinya penyakit ISPA. Karena rokok mengeluarkan asap, dimana asap rokok juga berpengaruh menimbulkan polusi udara dan terjadinya penyakit ISPA. Apabila kebiasaan merokok di dalam rumah dilakukan setiap hari, dapat berpengaruh kepada anggota keluarga yang lain. Dilihat dari dua kebiasaan tersebut, membakar sampah dan merokok di dalam rumah sangat berpotensi mempengaruhi kesehatan dan terjadinya penyakit ISPA. Hal ini dikarenakan perilaku dan pola pikir masyarakat di wilayah desa tersebut masih rendah dan perlu adanya kegiatan intervensi untuk meningkatkan pengetahuan dan pola pikir serta perubahan perilaku dari masyarakat.

Kegiatan intervensi ini dibuat dan dilakukan guna bertujuan untuk pencegahan penyakit ISPA sekaligus pemanfaatan terhadap barang bekas dan sampah yang ada di sekitar agar dapat digunakan kembali dan memiliki fungsi baru. Kegiatan ini memfokuskan kepada masyarakat melalui kegiatan kreativitas dan pemahaman sebagai wujud melakukan perubahan perilaku dan pola pikir agar dapat meningkatkan budaya hidup sehat sekaligus melakukan pencegahan penyakit ISPA. Masyarakat dapat memanfaatkan barang bekas dan sampah yang ada lingkungan sekitar sebagai bentuk pengelolaan sampah agar tidak dimusnahkan secara dibakar. Sampah organik dan non organik dapat dipilah terlebih dahulu dan dikelola dengan baik serta dapat bermanfaat bagi masyarakat. Karena banyaknya sampah dan barang bekas yang ada di lingkungan sekitar, maka dari itu lewat kegiatan intervensi ini selain guna pencegahan penyakit ISPA juga dapat dimanfaatkan kembali.

Banyak beberapa hal yang dapat diambil dan bermanfaat dari kegiatan intervensi ini, antara lain dapat meningkatkatkan pengetahuan dan pemahaman masyarakat, memberikan perubahan pola pikir dan perubahan perilaku agar menerapkan budaya hidup sehat sekaligus sebagai bentuk upaya pencegahan penyakit ISPA di lingkungan tersebut. Diharapkan dari kegiatan intervensi kesehatan tersebut dapat memberikan dampak positif dan antusiasme dari masyarakat agar dapat memberikan feedback dan berdampak positif bagi kehidupan masyarakat serta meningkatkan derajat kesehatan masyarakat dan kesehatan lingkungan.

\section{METODE PENGABDIAN MASYARAKAT}

Kegiatan pengabdian masyarakat melibatkan sasaran ibu rumah tangga di wilayah Desa Wotanngare, Kalitidu, Bojonegoro untuk berperan aktif dalam seluruh kegiatan. Kegiatan tersebut dilaksanakan bekerjasama dengan Perangkat Desa, Bidan dan 11 
orang mahasiswa Kesehatan Masyarakat Universitas Airlangga yang melaksanakan kegiatan Praktik Kerja Lapangan di wilayah Desa Wotanngare Kecamatan Kalitidu, Bojonegoro pada tanggal 3 Juli 2019 sampai dengan 9 Agustus 2019.

\section{Identifikasi Masalah}

Tahap pertama yang dilakukan adalah mengidentifikasi masalah kesehatan masyarakat di Desa Wotanngare. Kegiatan tersebut dilakukan dengan menggunakan pendekatan kepada stakeholder terkait yaitu Perangkar Desa dan Bidan Desa di Desa Wotanngare. Pendekatan yang dilakukan berguna untuk memperoleh informasi terkait gambaran tentang masalah kesehatan masyarakat di wilayah Desa Wotanngare. Identifikasi masalah dilakukan guna memperoleh data primer melalui wawancara mendalam dengan Bidan Desa di wilayah Desa Wotanngare. Berdasarkan hasil analisis data primer didapatkan hasil yaitu ditemukan kasus ISPA balita sebanyak 33 kasus dan Gizi kurang balita sebanyak 11 kasus.

\section{Prioritas Masalah}

Berdasarkan identifikasi masalah yang telah dilakukan, selanjutnya dilakukan prioritas masalah yang memiliki beberapa hal yang menjadi permasalahan untuk segera diberikan solusi dan penyelesaiannya. Dua masalah kesehatan di wilayah Desa Wotanngare yaitu ISPA dan Gizi Kurang, dilakukan prioritas masalah untuk segera diberikan solusi atas masalah kesehatan tersebut. Dari hasil penentuan prioritas masalah menggunakan metode USG dengan anggota kelompok, diperoleh masalah ISPA untuk dilakukan intervensi kesehatan.

\section{Tahap Perencanaan Intervensi}

Tahap perencanaan dilakukan melalui analisis komunitas dimana meliputi pengamatan keadaan dan lingkungan dari wilayah tersebut. Dilihat melalui keadaan sosial dari penduduk Desa Wotanngare, perilaku penduduk Desa Wotanngare dalam menganggap penyakit ISPA, lingkungan di wilayah Desa Wotanngare dalam akses menuju pelayanan kesehatan serta tingkat pendidikan pendudukan Desa Wotanngare.

Karakteristik sasaran yang akan diintervensi pada perencanaan kegiatan adalah ibu rumah tangga di wilayah Desa Wotanngare. Intervensi dilakukan untuk meningkatkan upaya pola hidup sehat dan perubahan pola pikir masyarakat. Ibu rumah tangga menjadi sasaran intervensi kegiatan karena dianggap sebagai orang yang berpengaruh dalam mengubah stigma dan pola pikir sehat di dalam keluarga.

Perencanaan pembuatan program membutuhkan tim atau anggota yang melibatkan Perangkat Desa Wotanngare, Bidan Desa, Kelompok Kader Posyandu serta Kelompok Ibu Rumah Tangga. Terkait masalah kesehatan ISPA, intervensi kegiatan yang dilakukan adalah untuk mencapai target perubahan perilaku masyarakat terkait upaya melakukan pola hidup sehat dan perubahan pola pikir sehat.

\section{Tahap Implementasi}

Kegiatan intervensi masalah ISPA yang pertama bernama NGOPI PAH (Ngobrol Pintar Kelola Sampah) yaitu dilakukan sosialisasi mengenai ISPA dan pentingnya pengelolaan sampah serta praktik pembuatan kompos dari sampah organik. Kegiatan kedua bernama KURAS MAH (Kurangi Asap Rokok di dalam Rumah) yaitu dilakukan sosialisasi mengenai ISPA dan pentingnya mengurangi asap rokok di dalam rumah serta 
demonstrasi pembuatan asbak yang memanfaatkan barang bekas yaitu kaleng bekas dan sosialisasi penggunaan asbak di luar rumah.

\section{Tahap Pemantauan dan Evaluasi}

Tahap pemantauan dan evaluasi dilakukan setelah kegiatan intervensi berlangsung yaitu dilakukan analisis kegiatan untuk mengetahui faktor pendukung dan penghambat dari keberlangsungan kegiatan yang telah dilakukan. Apabila dalam kegiatan intervensi mengalami suatu kendala maka dapat dievaluasi dan segera untuk mencari solusinya.

\section{HASIL DAN PEMBAHASAN}

Masalah kesehatan yang ada di wilayah Desa Wotanngare, paling banyak yaitu kasus ISPA yang dialami oleh balita. Berdasarkan hasil Fishbone terhadap penyakit ISPA, bahwa penyebab masalah kesehatan ISPA dipengaruhi oleh beberapa faktor. Dari segi faktor individu yaitu kurang optimalnya petugas kesehatan memberikan penyuluhan tentang ISPA pada balita, masih banyak masyarakat khususnya Kepala Keluarga yang merokok, personal hygiene yang kurang serta pengetahuan dan kesadaran yang rendah. Dari faktor sosial ekonomi yaitu rendahnya kemampuan masyarakat untuk melakukan pengobatan ketika mengalami sakit. Dari faktor lingkungan yaitu kebersihan lingkungan rumah yang kurang sehingga mudah terjadinya ISPA, kepadatan penduduk dan keterbatasan tempat tinggal serta kebiasaan masyarakat yang masih melekat yaitu memusnahkan sampah dengan cara dibakar.

Berdasarkan penyebab dari masalah tersebut dapat dilakukan suatu kegiatan intervensi untuk pencegahan terjadinya penyakit ISPA. Kegiatan intervensi bertujuan untuk mencegah terjadinya penyakit ISPA, menyejahterahkan masyarakat serta meningkatkan derajat kesehatan masyarakat. Kegiatan yang dilakukan dapat bermanfaat dalam kehidupan sehari-hari dan masyarakat dapat menerapkannya di lingkungan rumah. Kegiatan ini mendapatkan respon positif dan masyarakat sangat antusias dan semangat untuk mengikuti kegiatan intervensi tersebut. Pemanfaatan barang bekas dan sampah merupakan kunci dari kegiatan intervensi yang akan dilakukan kepada masyarakat. Alasan kegiatan intervensi dilakukan dengan didukung pemanfaatan barang bekas dan sampah, karena masyarakat dapat sekaligus memanfaatkan barang yang ada dengan kreativitas mereka untuk mencegah terjadinya penyakit ISPA dan memberikan manfaat kepada lingkungan.

Diharapkan melalui kegiatan intervensi dengan memanfaatkan barang bekas dan sampah tersebut dapat menambah pengetahuan, meningkatkan kesadaran serta membangkitkan kesejahteraan masyarakat untuk meningkatkan derajat kesehatan. Terdapat dua kegiatan intervensi dalam pencegahan penyakit ISPA, yang pertama Kegiatan NGOPI PAH (Ngobrol Pintar Kelola Sampah) yaitu bermanfaat untuk meningkatkan kesadaran dan pengetahuan ibu rumah tangga dalam pengelolaan sampah melalui kegiatan pengomposan dengan sampah organik serta kegiatan bank sampah. Kegiatan yang kedua adalah Kegiatan KURAS MAH (Kurangi Asap Rokok di dalam Rumah) yaitu bermanfaat untuk meningkatkan upaya mengurangi kebiasaan merokok anggota keluarga di dalam rumah dengan memanfaatkan barang bekas berupa kaleng bekas sebagai asbak untuk diletakkan di luar rumah. 


\section{Kegiatan NGOPI PAH (Ngobrol Pintar Kelola Sampah)}

Kegiatan NGOPI PAH (Ngobrol Pintar Kelola Sampah) merupakan kegiatan intervensi pertama yang akan dilakukan kepada masyarakat di wilayah Desa Wotanngare. Sasaran kegiatan ini adalah ibu rumah tangga di wilayah Desa Wotanngare. Kegiatan yang akan dilakukan dalam Kegiatan NGOPI PAH (Ngobrol Pintar Kelola Sampah) antara lain melakukan sosialisasi mengenai ISPA yang meliputi bahaya, faktor penyebab dan upaya pencegahan ISPA serta pentingnya pengelolaan sampah rumah tangga melalui kegiatan pengomposan dan bank sampah. Selain itu, dilakukan pula praktik pembuatan kompos dari sampah organik untuk upaya pengelolaan sampah agar tidak dilakukan pemusnahan sampah secara dibakar.

Kegiatan sosialisasi atau penyuluhan terkait penyakit ISPA kepada ibu rumah tangga dilakukan pada saat kegiatan pengajian ibu rumah tangga yang rutin setiap minggu dilaksanakan. Sosialisasi atau penyuluhan didukung pula dengan menggunakan media kesehatan yaitu berupa leaflet berisi bahaya ISPA, faktor penyebab ISPA dan upaya pencegahan ISPA. Leaflet tersebut bertujuan untuk memudahkan masyarakat untuk lebih memahami terkait penyakit ISPA. Kegiatan tersebut juga dilakukan sesi diskusi dan tanya jawab kepada ibu rumah tangga sebagai peserta sosialisasi.

Selain kegiatan sosialisasi atau penyuluhan terkait penyakit ISPA, terdapat pula kegiatan penyuluhan mengenai cara pengelolaan sampah yaitu sampah organik yang dapat digunakan menjadi pupuk kompos sedangkan sampah anorganik untuk bank sampah. Sampah organik yaitu seperti dedaunan, sayuran dan buah buahan untuk dimanfaatkan menjadi pupuk kompos. Kegiatan ini sangat bermanfaat untuk masyarakat melakukan pemanfaatan terhadap sampah yang ada di lingkungan wilayah Desa Wotanngare. Diharapkan dengan cara tersebut, kebiasaan masyarakat membakar sampah dihilangkan dan diganti dengan cara diubah menjadi pupuk kompos dan bank sampah.

Penyuluhan tersebut didukung pula dengan media kesehatan berupa leaflet, video pembuatan kompos dan contoh kompos yang sudah jadi. Selain penyuluhan, dilakukan pula demo pembuatan kompos dengan metode takakura. Diharapkan dari hasil demo pembuatan kompos tersebut, masyarakat dapat menerapkannya di kehidupan sehari-hari di lingkungan wilayah Desa Wotanngare. Kegiatan penyuluhan mengenai cara pengelolaan sampah dan kegiatan demo pembuatan kompos dilakukan di Balai Desa Wotanngare.

Peserta kegiatan yaitu ibu rumah tangga sangat antusias terhadap Kegiatan NGOPI PAH (Ngobrol Pintar Kelola Sampah), mulai dari kegiatan sosialisasi dan penyuluhan hingga kegiatan demo pembuatan sampah organik menjadi pupuk kompos dengan metode takakura. Ibu rumah tangga juga aktif berdiskusi dan tanya jawab kepada koordinator kegiatan sehingga mendapatkan pengetahuan mengenai penyakit ISPA, pengelolaan sampah dan pemanfaatan sampah organik dan anorganik. Selain itu, ketika kegiatan sosialisasi dan penyuluhan berlangsung, ibu rumah tangga sebagai peserta kegiatan menyimak dengan baik dan menangkah inti dari kegiatan penyuluhan tersebut. 

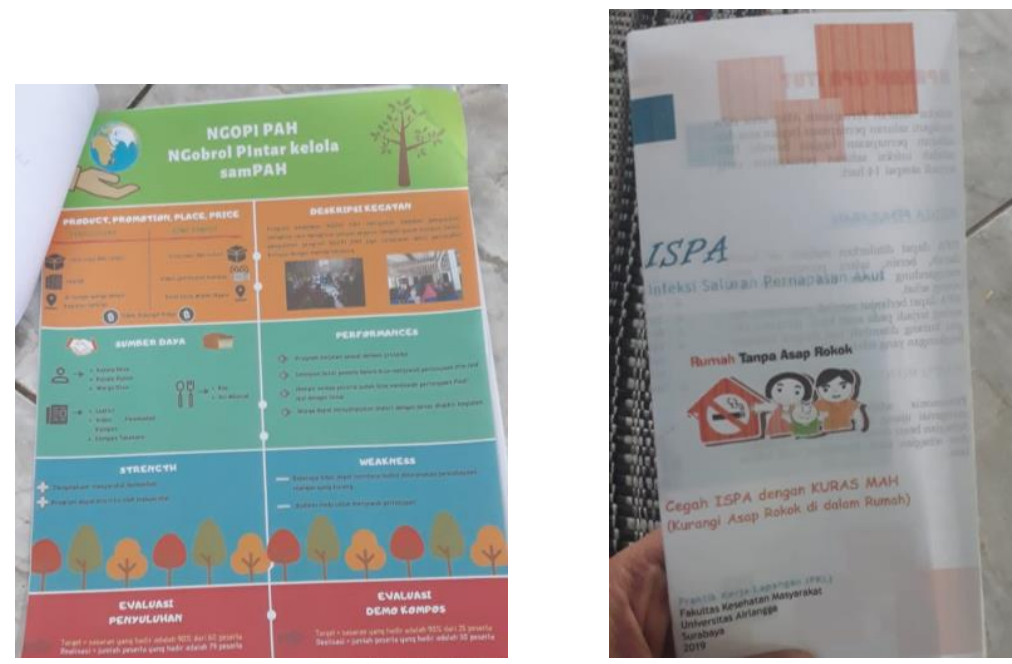

Gambar 1. Leaflet Penyuluhan ISPA dan Poster Kegiatan NGOPI PAH (Ngobrol Pintar Kelola Sampah)
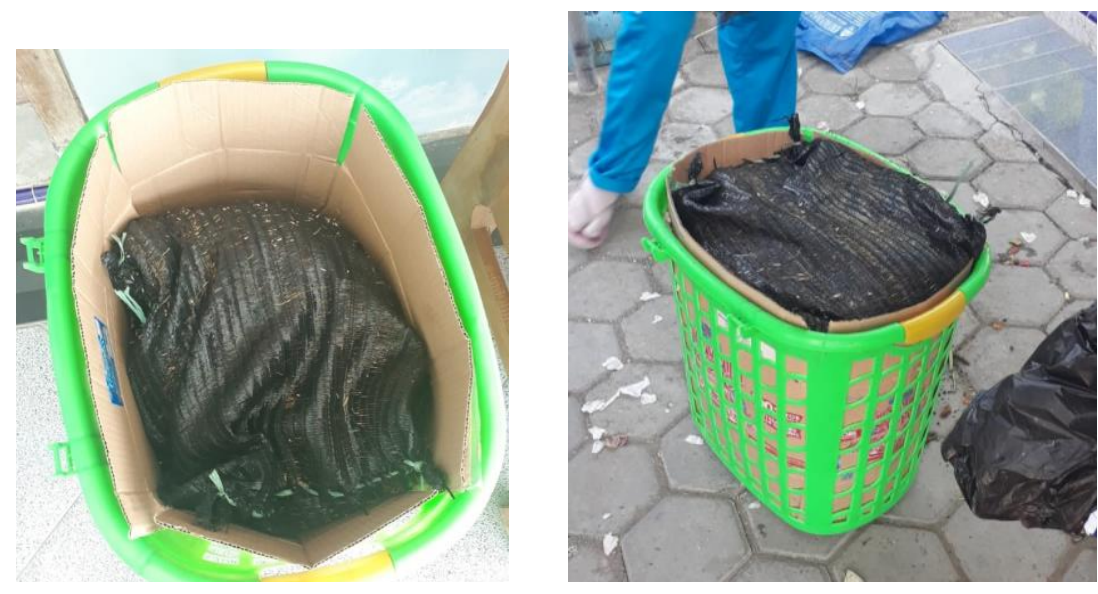

Gambar 2. Contoh Hasil Pembuatan Kompos Takakura
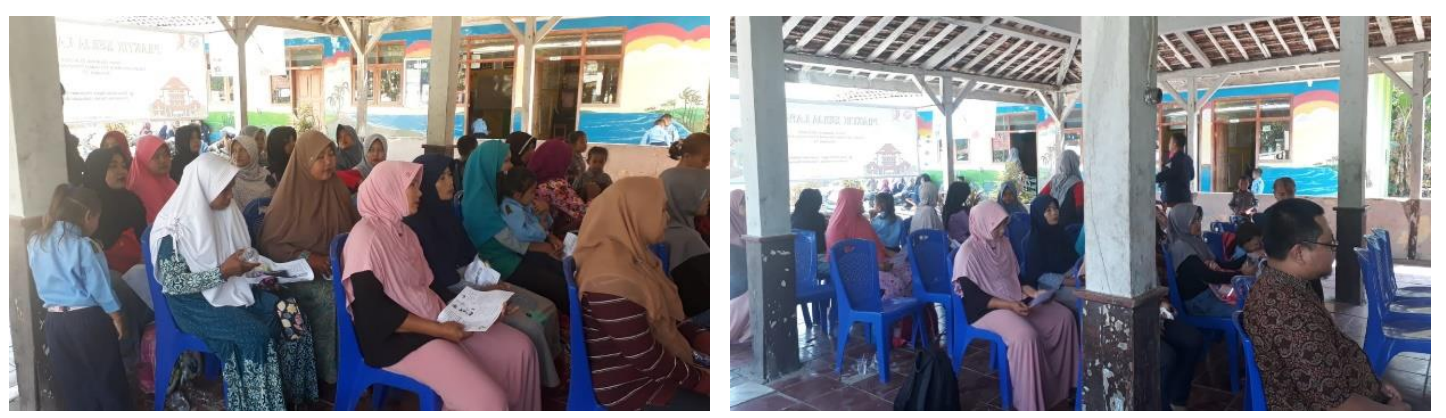

Gambar 3. Penyuluhan ISPA dan Pengelolaan Sampah 

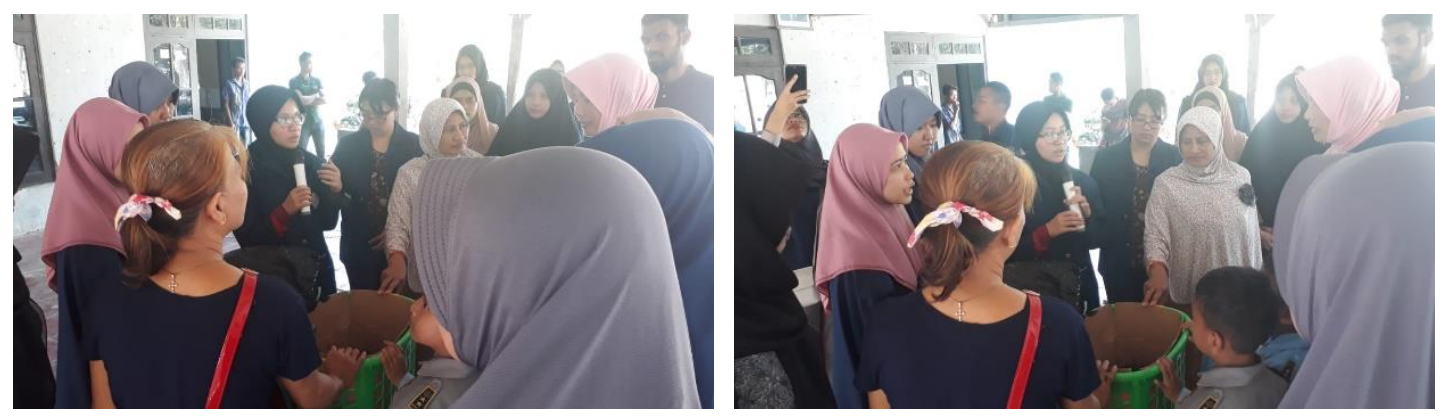

Gambar 4. Demo Pembuatan Kompos Takakura

\section{Kegiatan KURAS MAH (Kurangi Asap Rokok di dalam Rumah)}

Kegiatan KURAS MAH (Kurangi Asap Rokok di dalam Rumah) merupakan kegiatan intervensi kedua yang akan dilakukan kepada masyarakat di wilayah Desa Wotanngare. Sasaran kegiatan ini adalah ibu rumah tangga di wilayah Desa Wotanngare. Kegiatan yang akan dilakukan dalam Kegiatan KURAS MAH (Kurangi Asap Rokok di dalam Rumah) antara lain melakukan sosialisasi mengenai ISPA yang meliputi bahaya, faktor penyebab dan upaya pencegahan ISPA serta pentingnya mengurangi kebiasaan merokok dan asap rokok di dalam rumah sebagai salah satu upaya pencegahan penyakit ISPA. Selain itu, dilakukan pula praktik pembuatan asbak dari kaleng bekas yang berguna untuk diletakkan di luar rumah serta sosialisasi penggunaan asbak di luar rumah.

Rangkaian Kegiatan KURAS MAH (Kurangi Asap Rokok di dalam Rumah) dilakukan kepada ibu rumah tangga pada saat kegiatan pengajian ibu rumah tangga yang rutin setiap minggu dilaksanakan. Dalam kegiatan ini dilakukan pula sosialisasi atau penyuluhan terkait penyakit ISPA kepada ibu rumah tangga yang sama dilakukan dalam Kegiatan NGOPI PAH (Ngobrol Pintar Kelola Sampah) tersebut. Dikarenakan masalah kesehatan yang digunakan untuk intervensi kegiatan yaitu penyakit ISPA, maka dari itu penting untuk dilakukan penyuluhan terkait penyakit ISPA tersebut. kegiatan penyuluhan didukung dengan pemberian leaflet yang berisi bahaya ISPA, faktor penyebab ISPA dan upaya pencegahan ISPA. Namun pada Kegiatan KURAS MAH (Kurangi Asap Rokok di dalam Rumah) tersebut upaya pencegahan ISPA yaitu dengan cara melakukan upaya untuk mengurangi asap rokok dari anggota keluarga yang merokok di dalam rumah untuk merokok di luar rumah. Kegiatan ini juga dilakukan sesi diskusi dan tanya jawab agar peserta kegiatan yaitu ibu rumah tangga lebih paham dan mengerti mengenai penyakit ISPA dan pencegahannya.

Selain itu, dilakukan pula penyuluhan mengenai upaya mengurangi asap rokok di dalam rumah yang dilakukan oleh anggota keluarga yang merokok agar merokok di luar rumah. Upaya tersebut dilakukan dengan cara memanfaatkan barang bekas yang ada di sekitar agar dapat digunakan kembali dan memiliki fungsi baru. Pemanfaatan barang bekas tersebut dilakukan dengan cara pembuatan asbak yang memanfaatkan barang bekas berupa kaleng bekas. Kaleng bekas merupakan barang yang sangat banyak ada di lingkungan dan menjadi sampah apabila tidak dapat digunakan kembali. Maka dari itu agar memiliki fungsi baru, dapat dimanfaatkan sebagai upaya pencegahan penyakit ISPA dengan cara pembuatan asbak untuk anggota keluarga yang merokok. Pembuatan asbak dari kaleng bekas dilakukan dengan cara kaleng bekas yang sudah kosong diisi dengan pasir sampai padat. Asbak tersebut berguna untuk membuang puntung rokok 
sebelum masuk ke dalam rumah dan diletakkan di luar rumah. Sehingga apabila terdapat anggota keluarga yang merokok, diharuskan untuk merokok di luar rumah. Diharapkan dengan adanya praktik pembuatan asbak dari kaleng bekas tersebut masyarakat Desa Wotanngare dapat menerapkannya di rumah sehingga dapat memberikan solusi untuk rumah bebas asap rokok dan memberikan fasilitas untuk membuang puntung rokok sebelum masuk ke dalam rumah.

Selain antusias dan semangat dalam Kegiatan NGOPI PAH (Ngobrol Pintar Kelola Sampah), ibu rumah tangga juga antusias terhadap Kegiatan KURAS MAH (Kurangi Asap Rokok di dalam Rumah). Diharapkan dengan adanya kegiatan tersebut dapat menjadi upaya pencegahan penyakit ISPA dengan cara memanfaatkan barang bekas dan sampah yang ada di lingkungan wilayah Desa Wotanngare. Sehingga dapat meningkatkan derajat kesehatan masyarakat serta menjadikan seluruh anggota keluarga menjadi Keluarga Sehat.
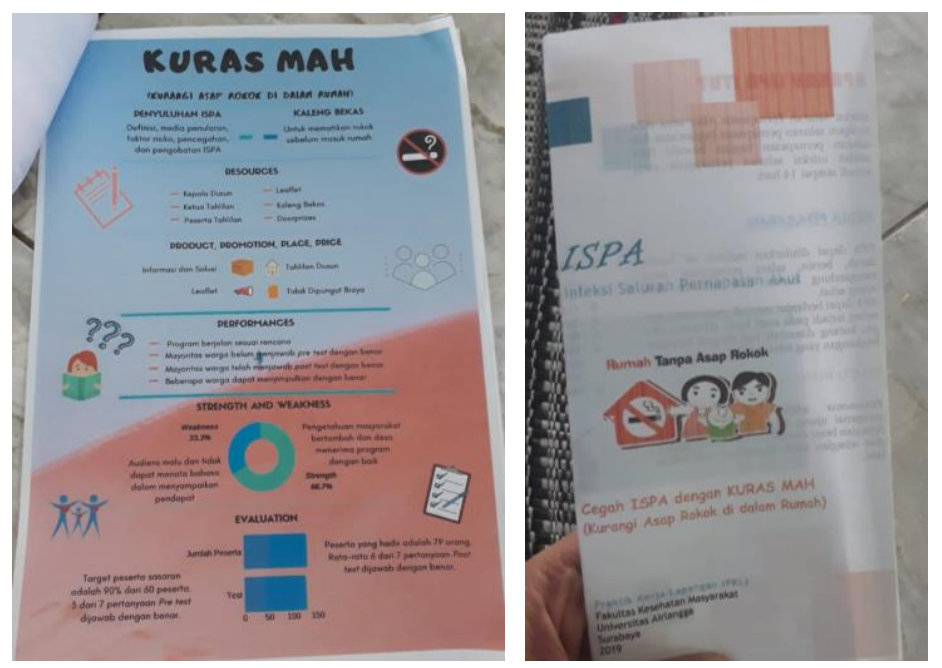

Gambar 5. Leaflet Penyuluhan ISPA dan Poster Kegiatan KURAS MAH (Kurangi Asap Rokok di dalam Rumah)
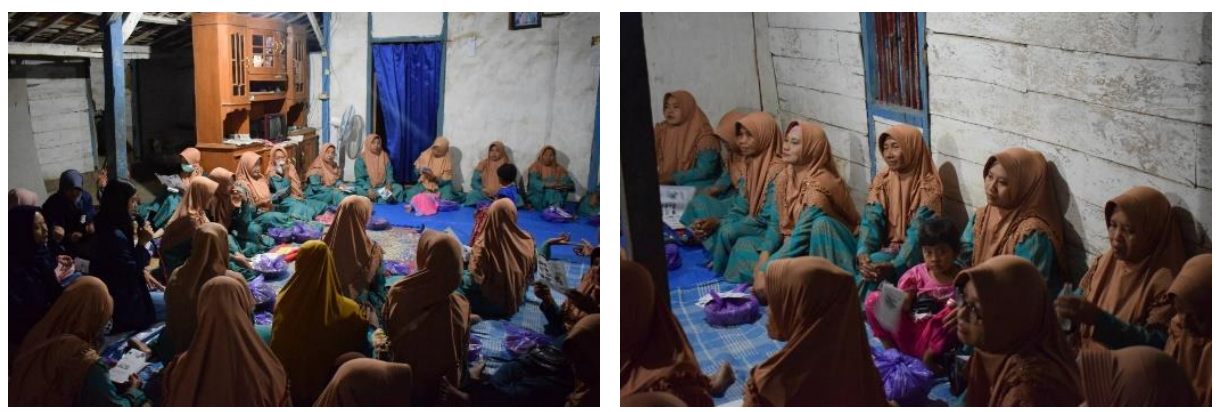

Gambar 6. Penyuluhan terkait Penyakit ISPA 

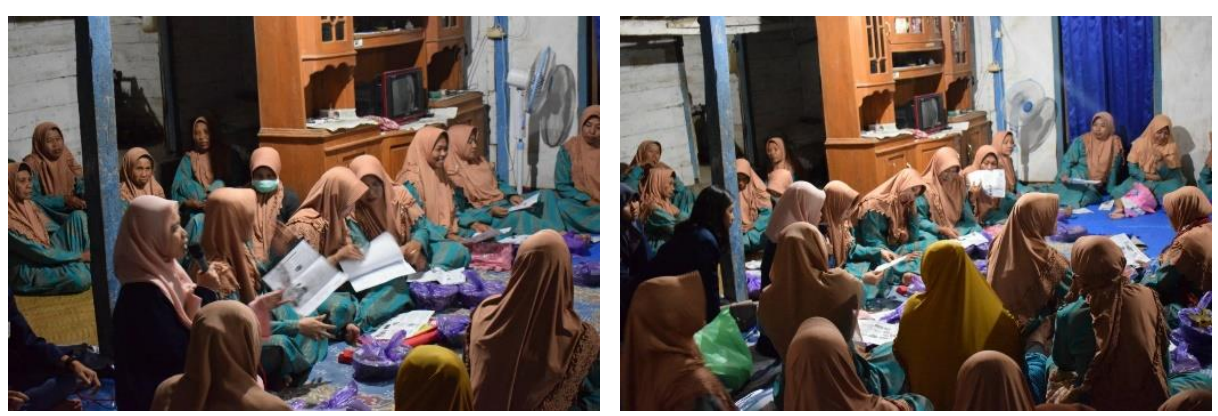

Gambar 7. Penyuluhan Pembuatan Asbak dengan Kaleng Bekas

\section{PENUTUP \\ Simpulan}

Kegiatan intervensi kesehatan dilakukan sebagai upaya terhadap pencegahan penyakit ISPA. Kegiatan NGOPI PAH (Ngobrol Pintar Kelola Sampah) dan Kegiatan KURAS MAH (Kurangi Asap Rokok di dalam Rumah) merupakan kegiatan positif yang bermanfaat untuk meningkatkan kesehatan masyarakat dan kesehatan lingkungan. Kegiatan tersebut memberikan dampak positif terhadap masyarakat dan antusias yang tinggi dalam mengikuti serangkaian kegiatan. Diharapkan dari kegiatan tersebut, dapat memberikan informasi dan pengetahuan mengenai penyakit ISPA dan upaya pencegahan penyakit ISPA dengan memanfaatkan barang bekas dan sampah yang ada di lingkungan sekitar serta masyarakat dapat menerapkannya di kehidupan sehari-hari. Sehingga kasus kejadian penyakit ISPA dapat diminimalisir dengan upaya pencegahan tersebut.

\section{Saran}

1. Pemerintah Desa Wotanngare memberikan dukungan sarana dan prasarana dalam hal peningkatan kesehatan masyarakat.

2. Pemerintah Desa Wotanngare melakukan monitoring dan evaluasi mengenai kesehatan di wilayah Desa Wotanngare.

3. Masyarakat Desa Wotanngare lebih memperhatikan masalah kesehatan di wilayah Desa Wotanngare khususnya penyakit ISPA.

4. Masyarakat Desa Wotanngare ikut berpartisipasi aktif dalam menjaga kesehatan lingkungan.

5. Masyarakat Desa Wotanngare mendukung dan melaksanakan program dari Desa. 


\section{DAFTAR PUSTAKA}

Kementerian Kesehatan Republik Indonesia. (2012). Pedoman Pemberantasan Penyakit Infeksi Saluran Pernapasan Akut untuk Penanggulangan Pneumonia Balita. Jakarta: Departemen Kesehatan Republik Indonesia.

Kementerian Kesehatan Republik Indonesia. (2012). Pedoman Pengendalian Penyakit Infeksi Saluran Pernapasan. Jakarta: Departemen Kesehatan Republik Indonesia.

Kementerian Kesehatan Republik Indonesia, 2019. Profil Kesehatan Indonesia 2018. Jakarta: Pusat Data dan Informasi Kementerian Kesehatan RI.

Mardiah, W., Mediawati, A., Setyorini, D. (2017). Pencegahan Penularan Infeksi Saluran Pernafasan Akut dan Perawatannya pada Balita di Rumah di Kabupaten Pangandaran. Dharmakarya: Jurnal Aplikasi Ipteks untuk Masyarakat Volume 6 No 3

Profil Desa Wotanngare Kecamatan Kalitidu Kabupaten Bojonegoro Tahun 2018

Roso, C. (2015). Peran Keluarga Prasejahtera dengan Upaya Pencegahan Infeksi Saluran Pernafasan Akut (ISPA) pada Balita di Desa Depok Kecamatan Kandeman Kabupaten Batang. Jurnal Keperawatan Volume 8 No 2

Wahyuningsih, S., Raodhah, S., Basri, S. (2017). Infeksi Saluran Pernafasan Akut (ISPA) pada Balita di Wilayah Pesisir Desa Kore Kecamatan Sanggar Kabupaten Bima. Higiene Volume 3 No 2

World Health Organization. (2012). Acute Respiratory Infections 